\section{2 Journal BiNET}

Journal of Bioscience and Agriculture Research

Home page: www.journalbinet.com/jbar-journal.html

\title{
Herbal extract (Ficus racemosa) restores the damages of diabetic pancreas both at gross and cellular levels: an in vivo study in mice
}

\section{Md. Mahmudul Amin ${ }^{\mathrm{b}}$, Sonali Bhakta ${ }^{\mathrm{b}}$, Md. Abdullah-Al-Mahmud ${ }^{\mathrm{a}}$, Md. Abdul Awal ${ }^{\mathrm{c}}$ and Shonkor Kumar Das ${ }^{b}$}

aDept. of Anatomy and Histology, Bangabandhu Sheikh Mujibur Rahman Agricultural University, Gazipur

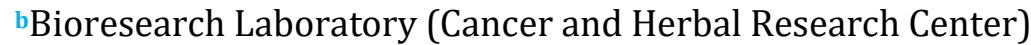

b,cDept. of Anatomy and Histology, Bangladesh Agricultural University, Mymensingh, Bangladesh

$\bowtie$ skdas76@yahoo.com (Das, S. K.), B+880-1716855186, Published: 26 April 2016

\section{ABSTRACT}

An in vivo investigation on the gross and cellular changes of the pancreas of Swiss albino mice treated with Ficus racemosa extract was carried out at the Bioresearch Laboratory, Department of Anatomy and Histology, Faculty of Veterinary Science, Bangladesh Agricultural University, Mymensingh. Twenty (20) Swiss albino mice (Mus musculus, age: 4-5 weeks, weight 25-28g, purchased from ICDDR,B) were used for this experiment and were grouped (each group has 5 mice) as the control group (C), diabetic control group (DC), glibenclamide treated group (GL) and Ficus racemosa extract treated group (FR) and provided with feed (standard mice pellets purchased from $I C D D R, B)$ and water ad libitum. Diabetes mellitus was induced by single intra-peritoneal injection of freshly prepared solution of alloxan monohydrate $(150 \mathrm{mg} / \mathrm{kg}$ body weight) dissolved in physiological saline in overnight fasted mice. The ethanolic extracts of Ficus racemosa fruit (250 mg/ $\mathrm{kg}$ body weight) was administered orally once daily for 30 days in comparison to a standard antidiabetic drug, glibenclamide $(600 \mu \mathrm{g} / \mathrm{kg}$ body weight). The uniformity of all the management practices was also maintained. The total experimental tenure was 30 days. At the end of the experiment, mice were ethically sacrificed and necessary samples were collected from the pancreas and were preserved, processed for slide preparation and stained ( $H \& E$ stain) for histomorphological investigation. Pancreas of the normal control group showed no morphological changes, whereas, both the colour and shape were significantly changed in the diabetic control group. The alteration was effectively restored in the standard anti-diabetic drug (glibenclamide) treated group as well as the Ficus racemosa extract treated group. Histologically, necrosis in the islets and focal acinar damages, found in the diabetic pancreas were restored to normal in the Ficus racemosa extract treated groups, and were significantly related to that of the effect produced by standard antidiabetic drug, glibenclamide. Therefore, it is assumed that the Ficus racemosa extract might be used as an anti-diabetic drug or as an adjuvant in the diabetic therapy. Results might aid to explore a frontier, inexpensive, safe and effective anti-diabetic drug in future.

Key Words: Ficus racemosa, Diabetes, Pancreas, Histo-morphology and Swiss albino mice

Cite article: Amin, M. A., Bhakta, S., Abdullah-Al-Mahmud, M., Awal, M. A. \& Das, S. K. (2016). Herbal extract (Ficus racemosa) restores the damages of diabetic pancreas both at gross and cellular levels: An in vivo study in mice. Journal of Bioscience and Agriculture Research, 08(01), 695-702. 


\section{Introduction}

Diabetes mellitus is a major metabolic disorder characterized by chronic hyperglycemia as a result of a relative or absolute lack of insulin or the actions of insulin (Mastan et al., 2009). Beta ( $\beta$ ) cells produce insulin which is the principal hormone that regulates the uptake of glucose from the blood into most cells of the body to use as fuel, for conversion to other needed molecules and to inhibit the process of gluconeogenesis. In diabetic animals, considerable reduction in the islets of Langerhans and depleted islets results in marked decrease of $\beta$-cells number and inadequate amount of insulin secretion (Gardner and Shoback, 2011). Insulin deficiency leads to metabolic aberrations in the animals namely increase blood glucose or hyperglycemia (Chude et al., 2001). Diabetes is the world's largest endocrine disease associated with increased morbidity and mortality rate (Sophia and Manoharan, 2007). Globally, an estimated 387 million people have diabetes in 2014, with type 2 diabetes making up about $90 \%$ of the cases (Shi and $\mathrm{Hu}, 2014$ ). This is equal to $8.3 \%$ of the adults' population, with equal rates in both men and women (Vos et al., 2012). The number of people with diabetes is expected to rise to 592 million by 2035 . Worldwide in the years 2012 to 2014, diabetes is estimated to have resulted in 1.5 to 4.9 million deaths per year, making it the 8th leading cause of death (IDF, 2014).

About $77 \%$ of people with diabetes live in low and middle income countries (IDF, 2014). The Indian subcontinent has emerged as the capital of this diabetes epidemic. The reported prevalence of diabetes in adults between the ages of 20 and 79 in the developing countries is as follows: India $8.31 \%$, Bangladesh 9.85\%, Nepal 3.03\%, Sri Lanka 7.77\% and Pakistan 6.72\% (Unwin et al., 2011). Bangladesh Institute of Research and Rehabilitation in Diabetes, Endocrine and Metabolic Disorders (BIRDEM) carried out a recent survey which revealed the prevalence of the disease in the rural population to be about 6.8\% (Rahim et al., 2007). Population growth, ageing of populations and urbanization with a sophisticated lifestyle is likely to direct to a high prevalence of the disease in Bangladesh. These factors will create a hazard to the economic status of the national healthcare systems (Haque et al., 2014). Diabetes is still not completely curable by the present anti diabetic agents. Insulin therapy is the only satisfactory approach in diabetic mellitus, even though it has several drawbacks like insulin resistance, anorexia, brain atrophy and fatty liver in chronic treatment (Nahar et al., 2010). Drug resistance, cardio-vascular complications, hypersensitivity, ketoacidosis, gastointestinal upset, coma, seizure or other neurological impairment are reported in the patients treated with oral anti-diabetics (Moller, 2001). Plant drugs and formulations are considered to be less toxic and free from side effects than synthetic ones (Mitra et al., 1996). In the search for new hypoglycemic compounds, it would be imprudent to ignore the traditional treatment of diabetes, which continues to provide the mainstay of therapy in region of the world where conventional drugs are not readily available or cannot be afforded (Amin et al. 2015).

Ficus racemosa plant has been viewed as an anti-diabetic plant since it became commercially available several decades ago. Hypoglycaemic and in vitro antioxidant activities of $F$. racemosa (Linn.) fruits ethanolic extracts were reported earlier (Zulfiker et al., 2011). However, its histo-morphological role in pancreas had hardly been included in the anti-diabetic study while using as medicinal plants to treat induced diabetes. F. racemosa have vast range of hypoglycemic phyto-constituents like alkaloids, $\beta$ sitosterol, flavonoids, lupeol, saponins, tannins and glycosides. These phyto-chemicals may delay the development of diabetic complications and correct the metabolic abnormalities by correcting altered carbohydrate metabolism, maintaining integrity and function of $\beta$-cells (Tiwari and Rao 2002). This plant extract controls muscle wasting i.e., reversal of gluconeogenesis and also improve insulin secretion and glycemic control resulted in body weight improvement (Varma et al., 2009). In this connection, the present study was aimed to investigate the restoration of the damages of diabetic pancreas both at gross and cellular levels treated with Ficus racemosa fruit extract in alloxan induced diabetic mice and to establish a new, safer and cost effective herbal drug for diabetic animals. 


\section{Materials and Methods}

\section{Plant description}

Ficus racemosa Linn. (Family: Moraceae), which is considered sacred, has golden coloured exudates and black bark (Joy et al., 2001). It's native to Australia, South-East Asia and the Indian subcontinent. The plant is frequently found around the water streams and is also cultivated (Joseph and Raj, 2010). It is a large deciduous tree up to $18 \mathrm{~m}$ high, leaves are ovate, ovate-lanceolate or elliptic, sub-acute, entire and petiolate and are shed usually by December and replenished by January and April, when the tree becomes bare for a short period. It has evergreen leaves; if it is close to a water source (Paarakh, 2009). Figs are subglobose or pyriform, red when ripe, borne in large clusters, on short, leafless branches emerging from the trunk and the main branches (Cooke, 1967). The tree is without aerial roots unlike its many family members (Anita and Mittal, 2011).

\section{Scientific classification}

Kingdom: Plantae

Division: Magnoliophyta

Class: Magnoliopsida

Order: Rosales

Family: Moraceae

Genus: Ficus

Species: Ficus racemosa

Synonym: Ficus glomerata Roxb.

Common names: Jaga dumur, Gulang dumur, Yajna dumbar, Udumbara, Gular fig, Cluster fig, Indian fig, Country fig, Goolar Fig, Atti etc.

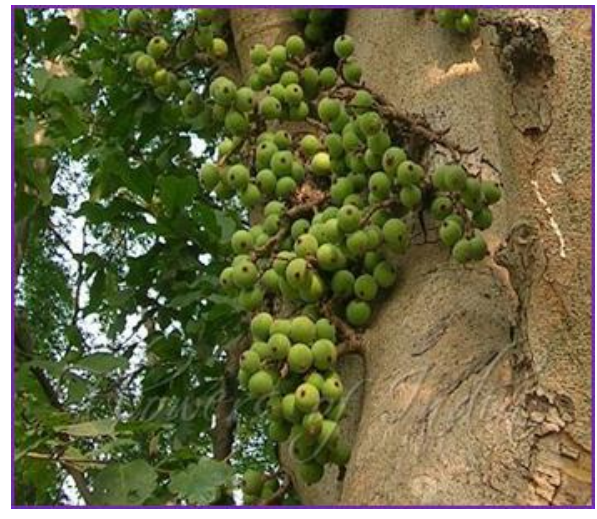

Figure 01. Fruits of $F$. racemosa.

Selection, maintenance and management of experimental animals: The study was carried out in the Department of Anatomy and Histology of Bangladesh Agricultural University in support of Ministry of Science and Technology, Government of Bangladesh, during January 2014 to June 2015. Young Swiss-albino mice of either sex (aged 4-5 weeks; average weight 25-28g) were purchased from the Animal Research Branch of the International Centre for Diarrhoeal Disease and Research, Bangladesh (ICDDR,B). The collected mice had neither any developmental disorders, detectable genital diseases nor other diseases that may cause any problem in the experiment or affect the result of the experiment. They were kept in standard environmental condition (room temperature $25.0 \pm 3.0{ }^{\circ} \mathrm{C}$, humidity $35-60 \%$ and 12 hours light and 12 hours dark cycle) for one week for acclimatization after their purchase. The mice were provided with experimental \& normal feeding (standard mice-pellets collected from ICDDR,B) and watering ad libitum. Excreta were removed from the cages on everyday. During the experimental period uniformity of the management practices was maintained. The mice were treated in accordance with the institutional and governmental guiding principles and the study was approved by the Ethics in Animal Research Committee of the Bangladesh Agricultural University.

Plant extraction method: The fruits of Ficus racemosa were collected from Bangladesh Agricultural University botanical garden. The botanical identity of this plant was determined by the descriptions given and authenticated by the Crop Botany Department of Bangladesh Agricultural University. The selected part (fruits) was cut into small pieces and dried in sunlight. The dried parts were then grinded to make fine powder with the help of a suitable grinder. Dry powder was dissolved in $95 \%$ ethanol (three times more in volume) in a clean, flat-bottomed conical flask for 5 days with occasional shaking and stirring. The whole mixture was successively filtered through a piece of clean, white cotton material and Whatman filter paper (Bibby RE 200, Sterilin Ltd., UK). The filtrate was evaporated using rotary evaporator (BUCHI Rota vapor R-114) connected with BUCHI water bath B480 at $70^{\circ} \mathrm{C}$ and dried ethanolic extract was obtained. Both powder and ethanol extracts were kept in the refrigerator (Bhuyan et al., 2010).

Preparation of dosage of plant extract: The crude extract obtained from fruit was dissolved in $99 \%$ dimethyl sulfoxide (DMSO) to prepare the solution where each $0.1 \mathrm{ml}$ contained $250 \mathrm{mg}$ Ficus 
racemosa extract. $0.1 \mathrm{ml}$ of each solution was administered by means of micropipette everyday/mice during treatment to achieve required dose of respective agents (Nahar et al., 2010).

Induction and confirmation of experimental diabetes: At first body weight of each mouse was calculated. Then required amount of alloxan monohydrate was measured according to the body weight by following the dose of $150 \mathrm{mg}$ of alloxan monohydrate/kg b.w. of mice. Then calculated amount of alloxan monohydrate/mice was dissolved in $0.1 \mathrm{ml}$ of sterile normal saline water. Diabetes was induced by single intra-peritoneal injection of alloxan monohydrate $(150 \mathrm{mg} / \mathrm{kg}$ body weight) dissolved in normal saline, after an overnight fast (access to water only) of 12 hours to make animals more susceptible to develop diabetes (Sophia and Manoharan, 2007). After 1 hour of alloxan administration, the mice were given feed ad libitum and 5\% dextrose solution in feeding bottle for a day to overcome the early hypoglycemic phase. On the third day, a blood drop was taken from the tail vain and glucose level was measured with the help of commercially available glucose strips and Kare Blood Glucose Meter, Taiwan. Mice with fasting blood glucose value of $9.7 \mathrm{mmol} / \mathrm{L}$ (equal to fasting serum glucose concentration of $11.0 \mathrm{mmol} / \mathrm{L}$ ) or above were considered as hyperglycemic and used for the experiments (Vasconcelo et al., 2011).

Experimental design: Twenty (20) Swiss albino mice were divided into four (4) groups (each of which had 5 mice) as the control group (C), diabetic control group (DC), glibenclamide treated group (GL) and Ficus racemosa extract treated group (FR). Total tenure for this experiment was 40 days. The first 10 (ten) days were for the induction of diabetic condition in mice and plant extract preparation and the following 30 (thirty) days were for treatment with standard drug and plant extracts. The 4 (four) groups of mice were as follows: Group-A: Control (C), mice served as positive control; Group-B: Diabetic Control (DC), diabetes was induced by single intra-peritoneal injection of alloxan monohydrate (150mg/kg body weight); Group-C: Glibenclamide treated (GL). Mice were administered with Glibenclamide @ 600 $\mathrm{\mu g} / \mathrm{kg}$ body weight orally once daily for 30 days; Group-D: Ficus racemosa extract treated (FR). Mice were administered with Ficus racemosa fruit ethanolic extract @ 250mg/kg body weight orally once daily for 30 days.

\section{Results and Discussion}

Gross study: The gross anatomical changes (colour \& shape) of the pancreas of the mice were presented in the figure 02-03. Pancreas of the normal control group showed no morphological changes, whereas, pale coloured and degenerated pancreases were observed in the diabetic group. The alterations were effectively restored in the Ficus racemosa herbal extract and the standard antidiabetic drug (glibenclamide) treated group. Sikder et al. (2011) also reported no abnormalities in the colour \& shape of the pancreas in the herbal extract treated rats when compared with the untreated control rats.
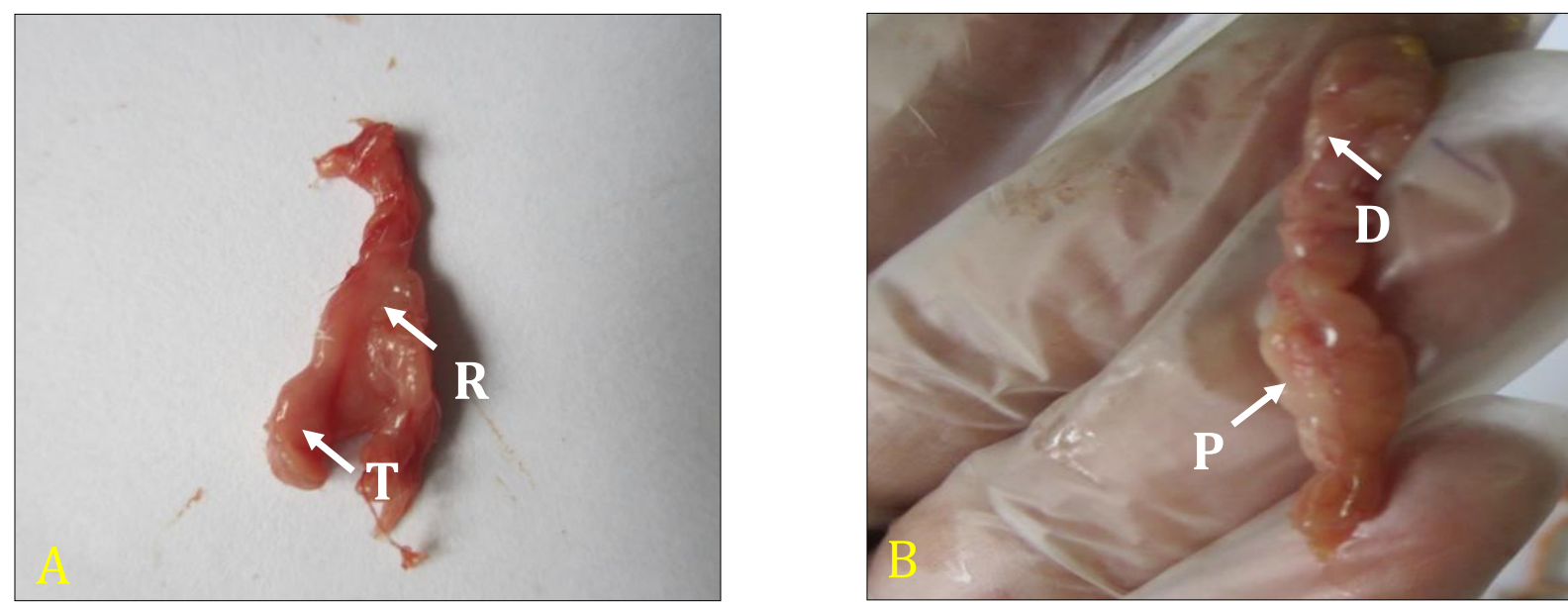

Figure 02 (A, B): A- Control (C) group showing red-cream (R) coloured, flat and irregularly triangular (T) shaped pancreas; B- Diabetic control (DC) group showing pale (P) and degenerated (D) pancreas. 

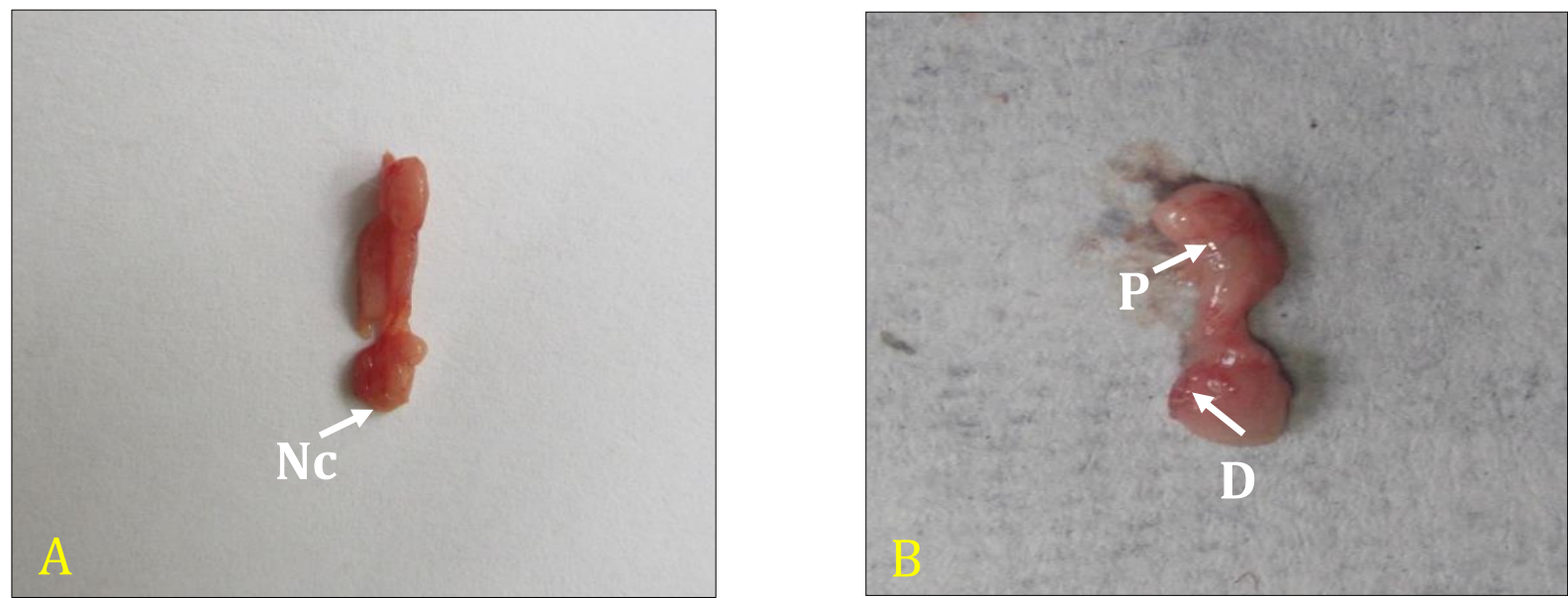

Figure 03 (A, B): A- Pancreas of the glibenclamide (GL) treated group showing almost normal colour (Nc) and shape; B- F. racemosa extract (FR) treated group showing less pale (P) colour \& slightly degenerated (D) pancreas in comparison to the diabetic control group.

Histological study: The light microscopic examination of the diabetic pancreas by $\mathrm{H} \& \mathrm{E}$ staining showed exocrine acini with focal acinar damage and considerable necrosis in the islets of Langerhans as well as decreased number of $\beta$ cells in comparing to the regular arrangement of the pancreatic acini and islets of Langerhans in the control group (Figure 04). Alloxan, a beta cytotoxin, was responsible for such damages of the pancreas (Omamoto et al., 1981). These findings were in agreement with the earlier reports by Rifaai et al. (2012); Krishna and Rao (2012); Singh and Gupta (2007).

The damages in the diabetic pancreas were remarkably restored by the Ficus racemosa ethanolic fruit extracts and standard anti-diabetic drug (glibenclamide) treatment (Figure 04-05). In the standard anti-diabetic drug (glibenclamide) treated group, almost normal acinar cells \& pancreatic islets were observed (Figure $05 \mathrm{~B}$ ). Pancreas of the F. racemosa extract (FR) treated mice showed restoration of focal acinar damage, regeneration of acinar cells and pancreatic islets (Figure $05 \mathrm{~A}$ ). The regeneration of the $\beta$-cells of the alloxan-destructed islets is probably due to the fact that pancreas contains stable (quiescent) cells which have the capacity of regeneration. Therefore, the surviving cells can proliferate to replace the lost cells. In this group the acinar cells also became normal and alpha $(\alpha) \&$ beta $(\beta)$ cells were present in normal proportion and regular arrangement. It was observed that the herb therapy brought back the alloxan-induced damaged pancreas to near normal state after 30 days of treatment and was significantly related to that of the effect produced by standard antidiabetic agent, glibenclamide.
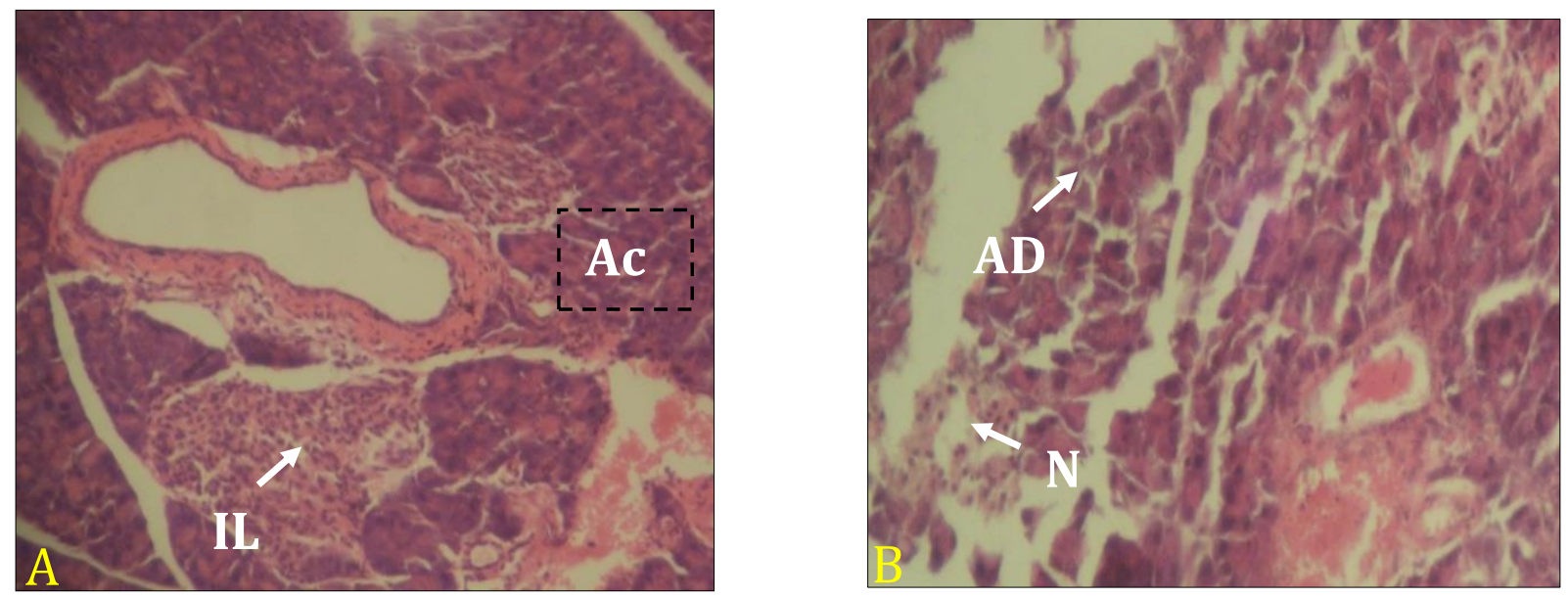

Figure 04 (A, B): A- Histological architecture of the pancreas in the control (C) group showing normal pancreatic acini (Ac) and islets of Langerhans (IL) (X10); B- Histological architecture of the pancreas of the diabetic control (DC) group showing acinar damage (AD) and considerable necrosis ( $\mathrm{N}$ ) in the islets of Langerhans (X10); H \& E stain. 

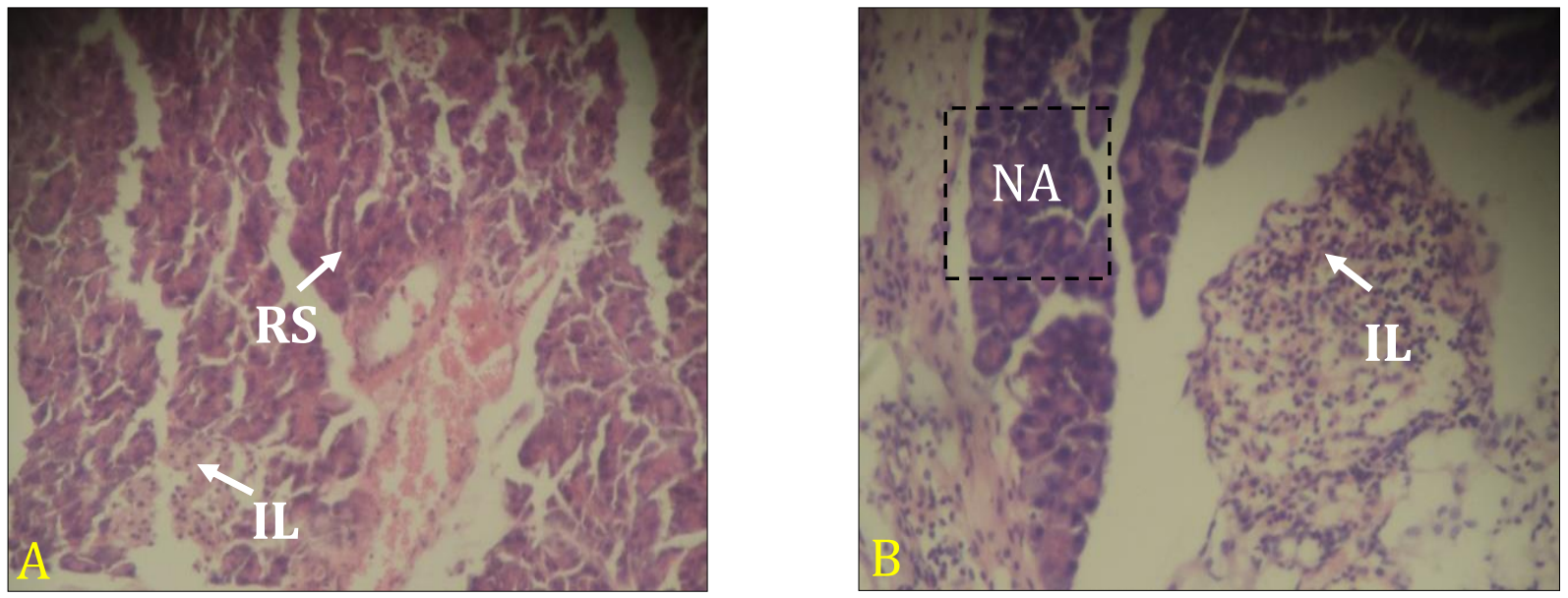

Figure 05 (A, B): A- Histological architecture of the F. racemosa extract (FR) treated pancreas showing acinar damage restoration (RS) and medium sized islets of Langerhans (X10); BHistological architecture of the glibenclamide (GL) treated pancreas showing normal acini (NA) and islets of Langerhans (IL) (X10); H \& E stain.

It is evident that with the application of more sophisticated extraction technique and quality control, along with advances in clinical research trial, the property of Ficus racemosa in treating and preventing diabetes will further improve and be as effective as the standard drug. With the treatment of F. racemosa and standard anti-diabetic drug, Munna and Saleem (2013); Rosalind et al. (2013); Ahmed and Urooj (2008) reported almost similar findings.

\section{Conclusion}

Plant parts of Ficus racemosa, which has been used as a crude drug for the welfare of mankind in old civilization, is now of a matter of concern due to its unexplored potentials obtained by various modern techniques. F. racemosa possess strong hypoglycemic compounds that have potential anti-diabetic activities and pancreatic regeneration capacity. Results from this study clearly indicated that the Ficus racemosa ethanolic fruit extract is much better as an anti-diabetic agent in effective restoration of histo-morphology of pancreas. Hence the research will ultimately aid the human being specially the poor people to have an inexpensive, safe and more effective drug for diabetes.

\section{Acknowledgements}

Authors are very much grateful to the Ministry of Science and Technology, Government of Bangladesh for financial support to complete this research.

\section{References}

[1]. Ahmed, F. \& Urooj, A. (2008). Antihyperglycemic activity of Ficus glomerata stems bark in Streptozotocin-induced diabetic rats. Global Journal of Pharmacology, 2(3), 41-45. http://www.idosi.org/gjp/2\%283\%2908/2.pdf

[2]. Amin, M. M., Sonali, B. \& Das, S. K. (2015). Anti-diabetic potential of Ficus racemosa: current state and prospect especially in the developing countries. Journal of Bioscience and Agriculture Research, 5(2), 65-72. http://dx.doi.org/10.18801/jbar.050215.56

[3]. Anita, R. S. \& Mittal, S. (2011). Ficus racemosa: phytochemistry, traditional uses and pharmacological properties: a review. International Journal of Recent Advances in Pharmaceutical Research, 4, 6-15.

[4]. Bhuyan, Z. A., Begum, R., Nuruzzaman, M., Shahdat, H. \& Ishtiaq, M. (2010). Antidiabetic effect of Syzygium cumini L. seed on type 2 diabetic rats. Dhaka University Journal of Biological Sciences, 19, 157-164. http://dx.doi.org/10.3329/dujbs.v19i2.8959 
[5]. Chude, M. A., Orisakawe, O. E., Afonne, O. J., Gamanial, K. S., Vongtau, O. H., Obi, E., Ghosh, S. \& Suryawanshi, S. A. (2001). Effect of Vinca rosea extracts in treatment of alloxan diabetic male albino rats. Indian Journal of Experimental Biology, 39(8), 748-759.

http://nopr.niscair.res.in/handle/123456789/23851

[6]. Cooke, T. (1967). The flora of presidency of Bombay (Reprinted ed.). Calcutta, India: Botanical Survey of India.

[7]. Gardner, D. G. \& Shoback, D. (2011). Greenspan's Basic \& Clinical Endocrinology. McGraw-Hill Medical, New York, USA. p. 129.

[8]. Haque, S., Ferdous, A., Iqbal, M. J., Halima, B. \& Alam, N. N. (2014). Effect of ethanolic extract of aloe vera (Aloe barbadensis) gel on blood glucose level of alloxan induced hyperglycaemic mice. Bangladesh Journal of Physiology and Pharmacology, 30(2), 25-31.

http://dx.doi.org/10.3329/bjpp.v30i2.22680

[9]. IDF (2014). International Diabetes Federation. Diabetes Atlas 6 IDF, Brussels, Belgium. https://www.idf.org/sites/default/files/EN_6E_Atlas_Full_0.pdf

[10]. Joseph, B. \& Raj, S. J. (2010). Phytopharmacological and phytochemical properties of three Ficus species -an overview. International Journal of Pharma and Bio Sciences, 1, 246-253.

[11]. Joy, P. P., Thomas, J., Mathew, S. \& Skaria, B. P. (2001). Medicinal Plants. In: T. K. Bose, J. Kabir, P. Das \& P. P. Joy (Eds.), Tropical Horticulture, pp. 123-125. Calcutta, India: Naya Prakash, Press.

[12]. Krishna, B. D. \& Rao, S. (2012). A histological study of the structural changes in the pancreas of diabetic rats. Journal of Indian Veterinary Association Kerala, 10, 10-14.

[13]. Mastan, S. K., Latha, T. B., Latha, T. S., Srikanth, A., Chaitanya, G. \& Kumar, K. E. (2009). Influence of methanolic extract of Syzygium cumini seeds on the activity of gliclazide in normal and alloxan induced diabetic rats. Pharmacologyonline, 3, 845-850.

http://pharmacologyonline.silae.it/files/archives/2009/vol3/092.Mastan.pdf

[14]. Mitra, S.K., Gopumadhavan, S., Muralidhar, T.S., Anturlikar, S.D. \& Sujatha, M.B. (1996). Effect of a herbomineral preparation D-400 in streptozotocin-induced diabetic rats. Journal of Ethnopharmacology, 54(1), 41-46. http://dx.doi.org/10.1016/0378-8741(96)01439-0

[15]. Moller, D. E. (2001). New drug targets for type 2 diabetes and the metabolic syndrome. Nature, 414, 821-827. http://dx.doi.org/10.1038/414821a

[16]. Munna, S. \& Saleem, M. T. S. (2013). Hypoglycemic and hypolipidemic activity of Ficus mollis leaves. Revista Brasileira de Farmacognosia, 23(4), 687-691.

http://www.scielo.br/pdf/rbfar/v23n4/aop05413.pdf

[17]. Nahar, L., Ripa, F. A., Zulfiker, A. H. M., Rokonuzzaman, M., Haque, M. \& Islam, K. M. S. (2010). Comparative study of antidiabetic effect of Abroma augusta and Syzygium cumini on alloxan induced diabetic rat. Agriculture and Biology Journal of North America, 1, 1268-1272. http://dx.doi.org/10.5251/abjna.2010.1.6.1268.1272

[18]. Omamoto, H., Ucgigata, Y. \& Hiroskitckan. (1981). STZ and alloxan induces DNA strand breaks and poly (ADP ribose) synthatase in pancreatic islet. Nature, 294, 284-286.

http://dx.doi.org/10.1038/294284a0

[19]. Paarakh, P. M. (2009). Ficus racemosa Linn. -an overview. Natural Product Radiance, 8, 84-90.

[20]. Rahim, M. A., Hussain, A., Khan, A. K. A., Sayeed, M., A., Ali, S. M. K. \& Vaaler, S. (2007). Rising prevalence of type 2 diabetes in rural Bangladesh: A population based study. Diabetes Research and Clinical Practice, 77(2), 300-305. http://dx.doi.org/10.1016/j.diabres.2006.11.010

[21]. Rifaai, R. A., El-Tahawy, N. F., Saber, E. A. \& Ahmed, R. (2012). Effect of quercetin on the endocrine pancreas of the experimentally induced diabetes in male albino rats: A histological and immunohistochemical study. Journal of Diabetes and Metabolism, 3, 182.

http://dx.doi.org/10.4172/2155-6156.1000182

[22]. Rosalind, T., Biman, K. D. \& Satya, B. P. (2013). Antihyperglycemic and antihyperlipidemic activity of Ficus auriculata Lour. leaf extract in streptozotocin induced diabetic mice. World Journal of Pharmacy and Pharmaceutical Sciences, 3(1), 412-427. www.wjpps.com/download/article/1388592978.pdf

[23]. Shi, Y. \& Hu, F. B. (2014). The global implications of diabetes and cancer. The Lancet, 383, 1947-1948. http://dx.doi.org/10.1016/S0140-6736(14)60886-2.

[24]. Sikder, M. A. A., Kaisar, M. A., Rahman, M. S., Hussain, M. \& Rashid, M. A. (2011). Active hypoglycemic fraction from Syzygium cumini L. seed and its safety profile. Bangladesh Pharmaceutical Journal, 14(2), 87-91. 
http://www.bpj-bd.com/index.php/current-issue/category/4-volume-14-no-2-july2011?download=109:article-03

[25]. Singh, N. \& Gupta, M. (2007). Effects of ethanolic extract of Syzygium cumini (Linn) seed powder on pancreatic islets of alloxan diabetic rats. Indian Journal of Experimental Biology, 45, 861-867.

http://nopr.niscair.res.in/bitstream/123456789/5343/1/IJEB\%2045\%2810\%29\%20861867.pdf

[26]. Sophia, D. \& Manoharan, S. (2007). Hypolipidemic activities of Ficus racemosa Linn. bark in alloxan induced diabetic rats. African Journal of Traditional, Complementary and Alternative Medicines, 4(3), 279-288. http://www.ncbi.nlm.nih.gov/pmc/articles/PMC2816482/

[27]. Tiwari, A. K. \& Rao, J. M. (2002). Diabetes mellitus and multiple therapeutic approaches of phytochemicals: present status and future prospects. Current Science, 83(1), 30-38. http://www.currentscience.ac.in/Downloads/download_pdf.php?titleid=id_083_01_0030_003 8_0

[28]. Unwin, N., Whiting, D., Guariguata, L., Ghyoot, G. \& Gan, D. (2011). IDF Diabetes Atlas. Brussels, Belgium. p. 231.

[29]. Varma, C., Fernandes, J., Ronald, F. \& Subramanyam, E. V. S. (2009). Hypoglycemic and antihyperglycemic activity of methanolic root extract of Ficus racemosa in normal and streptozotocin induced diabetic rats. Pharmacologyonline, 2, 656-666. http://pharmacologyonline.silae.it/files/archives/2009/vol2/067.Fernandes.pdf

[30]. Vasconcelo, C.F.B., Maranhão, H.M.L., Batista, T.M., Carneiro, E.M., Ferreira, F., Costa, J., Soares, L.A.L., Sá, M.D.C., Souza, T.P., \& Wanderley, A.G. (2011). Hypoglycemic activity and molecular mechanisms of Caesalpinia ferrea bark extract on streptozotocin-induced diabetes in Wistar rats. Journal of Ethnopharmacology, 137(3), 1533-1541. http://dx.doi.org/10.1016/j.jep.2011.08.059

[31]. Vos, T., Flaxman, A. D., Naghavi, M., Lozano, R., Michaud, C., Ezzati, M., Shibuya, K., Salomon, J. A., Abdalla, S. \& Aboyans, V. (2012). Years lived with disability (YLDs) for 1160 sequelae of 289 diseases and injuries 1990-2010: a systematic analysis for the Global Burden of Disease Study 2010. The Lancet, 380(9859), 2163-2196. http://dx.doi.org/10.1016/S0140-6736(12)61729-2.

[32]. Zulfiker, A. H. M., Saha, M. R., Sarwar, S., Nahar, L., Hamid, K. \& Rana, M. S. (2011). Hypoglycemic and in vitro antioxidant activity of ethanolic extracts of Ficus racemosa Linn. fruits. American Journal of Scientific and Industrial Research, 2, 391-400. http://dx.doi.org/10.5251/ajsir.2011.2.3.391.400

\section{How to cite this article?}

\section{APA (American Psychological Association)}

Amin, M. A., Bhakta, S., Abdullah-Al-Mahmud, M., Awal, M. A. \& Das, S. K. (2016). Herbal extract (Ficus racemosa) restores the damages of diabetic pancreas both at gross and cellular levels: An in vivo study in mice. Journal of Bioscience and Agriculture Research, 08(01), 695-702.

\section{MLA (Modern Language Association)}

Amin, M. A., Bhakta, S., Abdullah-Al-Mahmud, M., Awal, M. A. \& Das, S. K. "Herbal extract (Ficus racemosa) restores the damages of diabetic pancreas both at gross and cellular levels: An in vivo study in mice". Journal of Bioscience and Agriculture Research, 08.01(2016), 695-702.

\section{Chicago/Turabian}

Amin, M. A., Bhakta, S., Abdullah-Al-Mahmud, M., Awal, M. A. \& Das, S. K. "Herbal extract (Ficus racemosa) restores the damages of diabetic pancreas both at gross and cellular levels: An in vivo study in mice". Journal of Bioscience and Agriculture Research, 08, no. 01 (2016), 695-702. 